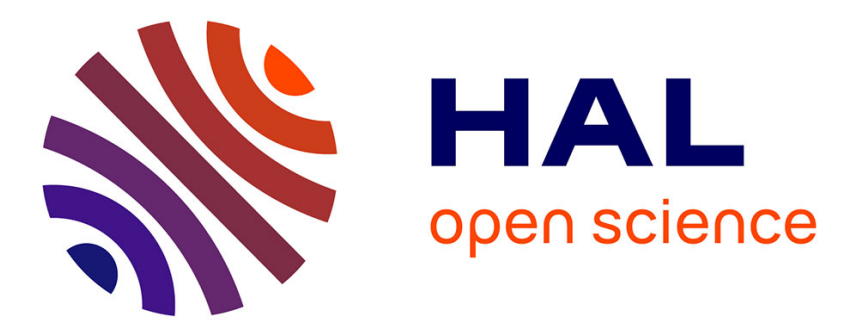

\title{
Coupled Experimental / Numerical Approach to Determine the Creep Behavior of Zr-4 Cladding Under LOCA Condition
}

Damien Campello, Nicolas Tardif, Marie-Christine Baietto, Michel Coret, Jean Desquines

\section{To cite this version:}

Damien Campello, Nicolas Tardif, Marie-Christine Baietto, Michel Coret, Jean Desquines. Coupled Experimental / Numerical Approach to Determine the Creep Behavior of Zr-4 Cladding Under LOCA Condition. iDICs 2016, Nov 2016, Philadelphia, United States. 10.1007/978-3-319-51439-0_54 . hal01863191

\section{HAL Id: hal-01863191 \\ https://hal.science/hal-01863191}

Submitted on 28 Aug 2018

HAL is a multi-disciplinary open access archive for the deposit and dissemination of scientific research documents, whether they are published or not. The documents may come from teaching and research institutions in France or abroad, or from public or private research centers.
L'archive ouverte pluridisciplinaire HAL, est destinée au dépôt et à la diffusion de documents scientifiques de niveau recherche, publiés ou non, émanant des établissements d'enseignement et de recherche français ou étrangers, des laboratoires publics ou privés. 


\title{
Coupled Experimental / Numerical Approach to Determine the Creep Behavior of $\mathrm{Zr}-4$ Cladding Under LOCA Condition.
}

\author{
D. Campello ${ }^{1}$, N. Tardif ${ }^{1}$, M.-C. Baietto ${ }^{1}$, M. Coret $^{2}$, J. Desquines ${ }^{3}$ \\ ${ }^{1}$ Université de Lyon, CNRS, INSA-LYON, LaMCoS UMR 5259, 20 Avenue Albert Einstein, F69621 Villeurbanne Cedex, \\ France \\ ${ }^{2}$ GeM (UMR 6183), Ecole Centrale de Nantes, 1 rue de la Nö̈, 44321 Nantes, France \\ ${ }^{3}$ IRSN/PSN-REX/SEREX/LE2M, Saint Paul lez Durance, France
}

\begin{abstract}
The thermo-mechanical behavior of Zircaloy-4 fuel rods under Loss-Of-Coolant Accident (LOCA) conditions is investigated. A custom experimental setup is dedicated to the high-temperature creep ballooning study of $90 \mathrm{~mm}$ long cladding samples. Creep tests were performed under an inert environment (argon), for temperatures from 750 to $850{ }^{\circ} \mathrm{C}$ and internal pressures ranging from 1 to $5 \mathrm{MPa}$. As the high-temperature creep of metals is strongly influenced by the temperature, the setup allow for a heterogeneous thermal distribution along the specimen. A unique test provides a rich database about the steady-state creep of the alloy. A first campaign is dedicated to bare Stress Relieved Annealed Zr-4. Creep-rates are computed along a generatrix of the tube using 2-Dimensional Digital Image Correlation (2D-DIC) and are correlated to thermal distribution measurements allowed by Near Infra-Red Thermography (NIRT). As-received Zr-4 behavior laws are determined using Finite Element Model Updating (FEMU). Norton exponents and activation energies are determined for thermal-mechanical conditions of the performed tests.
\end{abstract}

Keywords: 2D-DIC, NIRT, FEMU, creep power-law, Zircaloy-4.

\section{INTRODUCTION}

Loss-Of-Coolant of the primary loop is a complex multi-physical design basis accident. The study of the thermal mechanical and thermal hydraulics behavior of a fuel rod assembly is the context of PERFROI project [1]. It relies on both experimental and modeling activities about the flow blockage caused by fuel rods deformation, fuel fragment relocation and the potential loss of cladding integrity. In this framework, the ballooning behavior of fuel rod claddings submitted to high temperature and internal pressure is investigated.

Creep-tests and thermal ramps are usually performed in order to investigate the cladding behavior under LOCA conditions [2-5]. The setups proposed in this literature provide on a test a single temperature condition assuming thermal field is homogeneous when testing. A unique stress condition is often investigated. The number of the tests to be performed is consequent in order to accurately determine material parameters.

The study focuses on creep ballooning tests. Creep power-law in equation (1) is assumed to well model the secondarycreep behavior $\dot{\varepsilon}_{e q}$ of zirconium alloys [6] depending on the temperature $T$ and the von Mises stress $\sigma_{v M}$. The multiplicative coefficient $A$, the Norton exponent $n$ and the activation energy $Q$ are widely investigated with experimental studies.

$$
\dot{\varepsilon}_{e q}(\sigma, T)=A \cdot \sigma_{v M}^{n} \cdot e^{\frac{-Q}{R \cdot T}}
$$

These creep parameters depend on the temperature and applied stress conditions.

\section{SETUP}

The experimental setup initially designed by Tardif et al. [1] is upgraded to test Zircaloy-4 claddings under inert atmosphere using argon gas [8]. The thermo-mechanical loading applied to the specimen is represented in Fig. 1.

The tube is first heated using an induction system, and then 3 successive internal pressure levels are applied using argon gas. The bottom end effect is compensated. The bench is fitted to perform 2D-DIC [2] and NIR measurements [3].

Axial and hoop displacements fields are calculated in the ROI using a 2D-DIC algorithm. It is performed using Ufreckles software developed at LaMCoS by J. Réthoré [15]. The conservation of the optical flow is solved using a non-linear leastsquare method relying on a finite element basis. Performing 2D-DIC on tubular specimen is not common considering the 3D geometry. Uncertainties related to out-of-plane displacement (ballooning) have been estimated and are negligible with respect to the cladding deformation when steady-state creep rates are calculated. The equivalent steady-state creep-rates are calculated assuming material incompressibility and using the von Mises criterion. 


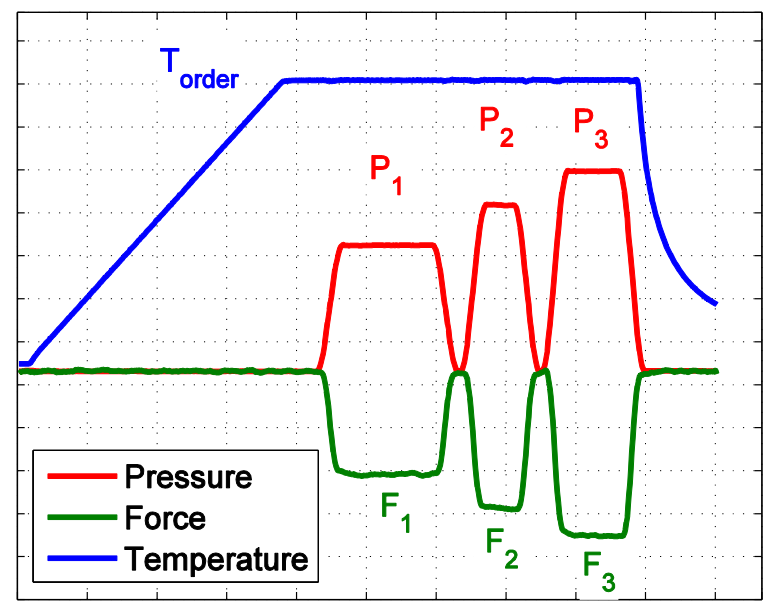

Test time

Fig. 1 Schematic thermal mechanical loadings applied to the specimen

The second digital image processing is dedicated to near infra-red measurements [9]. Standard cameras (with silicon detectors) are preferred to infra-red cameras in order to higher the image definition. The $K_{1}$ and $K_{2}$ parameters of the radiometric model detailed in equation (2) are calibrated using the data measured during the heating part of the test on the specimen itself.

$$
T=\frac{K_{1}}{\ln \left(\frac{K_{2}}{I}+1\right)}
$$

\section{RESULTS}

The steady-state creep rate and temperature axial distributions measured in the gauge length $\left(\mathrm{z}_{0}=20 \mathrm{~mm}\right)$ on a specimen heated up to $850^{\circ} \mathrm{C}$ are plotted in Fig. 3 .
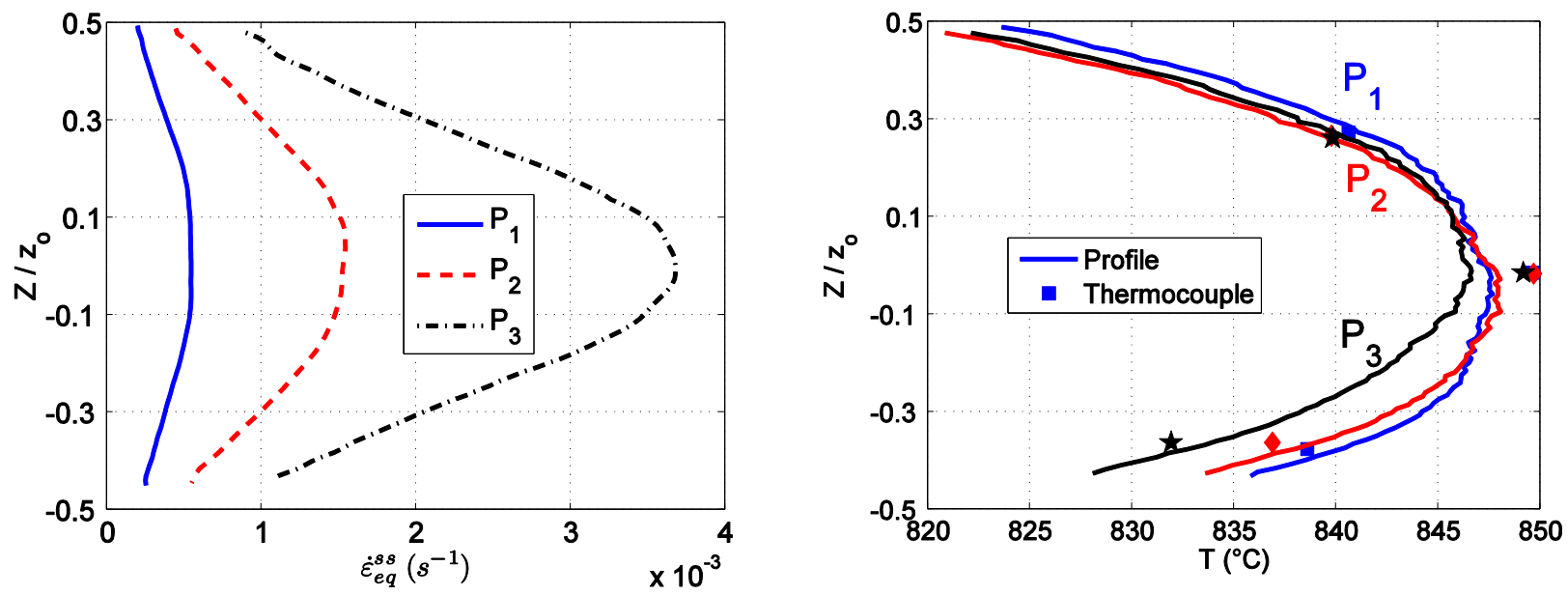

Fig. 2 Kinematic and thermal axial distributions

The thermal distribution clearly induces a variation of the creep-rates along the height of the specimen. The heterogeneous thermo-mechanical conditions are fully capitalized with the modeling of the tests. An iterative Gauss-Newton algorithm is then performed in order to lower the error between experimental creep-rate logarithms and calculated ones. A constitutive behavior law is determined using the data of a unique test. The measurements of nine experiments were processed in order 
to map the Norton exponent and the activation energy as represented in Fig. 3.
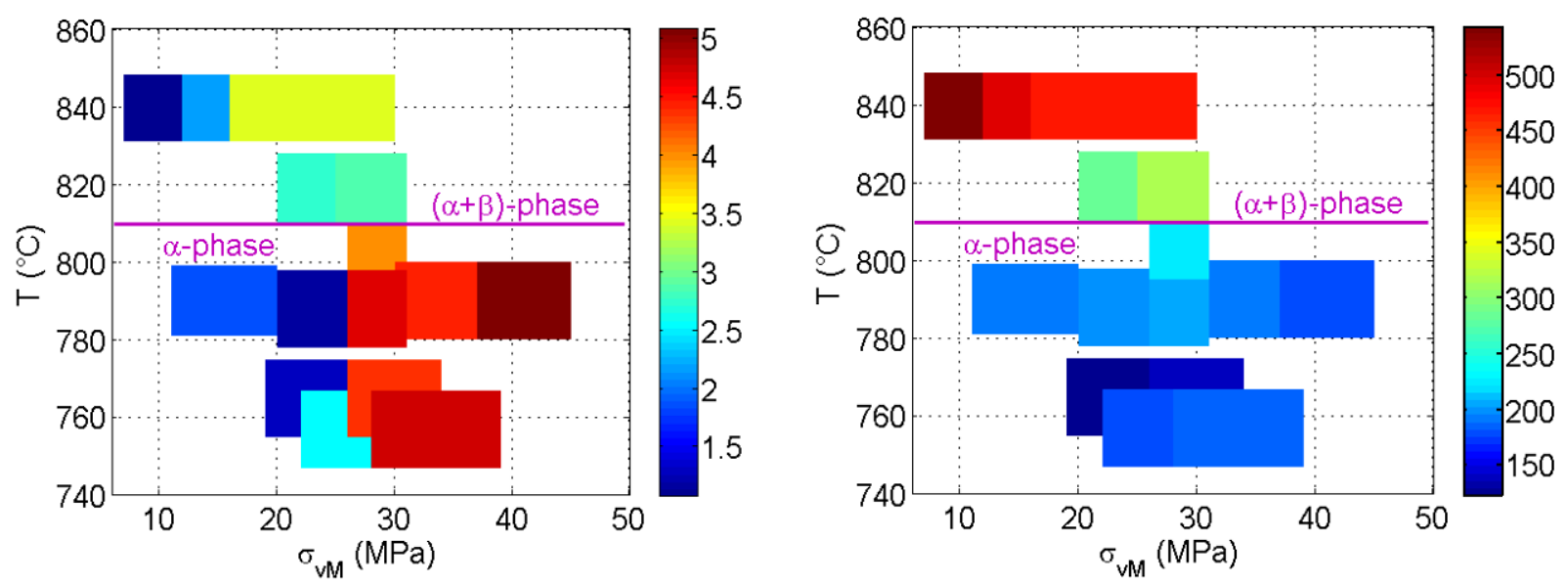

Fig. 3 Norton exponent and activation energy determined in the domain of the study using data of 9 experiments

The results are in a good agreement between each other and are consistent with literature data. A stress of $25 \mathrm{MPa}$ is determined in the $\alpha$-phase domain of $\mathrm{Zr}-4$ as a boundary between diffusion and dislocation creep mechanisms. The microstructure of the alloy is changing from $\alpha$ to $\alpha+\beta$ phase at a temperature of $820{ }^{\circ} \mathrm{C}$. As an effect, the determined activation energy is changing from around $180 \mathrm{~kJ} / \mathrm{mol}$ to $300-400 \mathrm{~kJ} / \mathrm{mol}$ in this domain.

\section{CONCLUSION}

A FEMU methodology was performed in order fully capitalize high-temperature creep ballooning tests data and determine the parameters a steady-state creep power-law. The ballooning structural effect are accounted for using FEM granting access to the true stress level and state over a $20 \mathrm{~mm}$ gauge length. Results of seven tests are detailed in this paper addressing to thermal conditions ranging from 750 to $850^{\circ} \mathrm{C}$ and von Mises stresses in a range of 7 to $48 \mathrm{MPa}$.

The effect of applied stress on the Norton exponent is evidenced in the study for both $\alpha$-phase and $(\alpha+\beta)$-phase domains. The determined stress exponent magnitudes are very consistent with literature data depending on the thermo-mechanical test conditions.

The activation energy parameter is very sensitive to the thermo-mechanical conditions and remains valid within a limited temperature and stress ranges to the authors' knowledge. The beginning of the $(\alpha+\beta)$-phase domain is clearly identified with the activation energy increase.

\section{ACKNOWLEDGMENTS}

The study was performed in the framework of the PERFROI ANR project ( $\mathrm{n}^{\circ}$ ANR-11-RSNR-0017-01). The authors would like to acknowledge all the participants of the project: EDF, IRSN-SEREX, LEMTA, Ecole Centrale of Paris.

\section{REFERENCES}

[1] Repetto, G., Dominguez, C., Durville, B., Carnemolla, S., Campello, D., Tardif, N., and Gradeck, M., "The R\&D PERFROI project on the thermal mechanical and thermal hydraulics behaviors of a fuel rod assembly during Loss-Of-Coolant Accident," Proceedings of the Nureth16, Chicago, USA, August 30-September 4, (2015).

[2] Busby, C., and Marsh, K., "High temperature, time-dependent deformation in internally pressurized Zircaloy-4 tubing (LWBR Development Program), " in Tech. report, Colorado Cooperative Wildife Research Unit, Fort Collins, USA, (1974).

[3] Kaddour, D., Frechinet, S., Gourgues, A., Brachet, J., Portier, L., and Pineau, A., "Experimental determination of creep properties of zirconium alloys together with phase transformation, "Scripta Materialia, 51, 6, (2004), 515-519.

[4] Rosinger, H. E., Bera, P. C., and Clendening, W. R., "The steady-state creep of Zircaloy-4 fuel cladding from 940 to $1873 \mathrm{~K}$ ", in Tech. report, Atomic Energy of Canada Limited, (1978).

[5] Réocreux, M., and de Martinville, E. S., "A study of fuel behavior in PWR design basis accident: and analysis of results from the PHEBUS and EDGAR experiments, ” Nuclear Engineering and Design, 124, 3, (1990), 363-378.

[6] Hayes, T. A., and Kassner, M., "Creep of zirconium and zirconium alloys," Metallurgical and Materials Transactions A, 37A, (August 2006), 2389-2396.

[7] Tardif, N., Coret, M., and Combescure, A., "Experimental study of the fracture kinetics of a tubular $16 \mathrm{MnNiMo5}$ steel specimen under biaxial loading at 900 and $1000^{\circ} \mathrm{C}$. Application to the rupture of a vessel bottom head during a core meltdown accident in a pressurized water reactor," Nuclear Engineering and Design, 241, 3, (2011), 755-766.

[8] Campello, D., Tardif, N., Baietto, M.-C., Coret, M., Desquines, J., "Secondary creep behavior of Zr-4 claddings under LOCA conditions," Proceedings of the TOPFUE 2016, Boise, USA, September 11-16, (2015). 